\title{
Professionalismi, õppimise ja identiteedi kontseptsioonide sidumine
}

\author{
Manon C. P. Ruijters ${ }^{\mathrm{a}}$, P. Robert-Jan Simons ${ }^{\mathrm{b} 1}$ \\ ${ }^{a}$ Amsterdami Vabaülikool \\ ${ }^{b}$ Visie op leren, Amsterdam
}

\begin{abstract}
Annotatsioon
Selles kontseptuaalses artiklis püüame ühendada mõned oma varasematest käsitustest uueks sidusaks õppija identiteedi mudeliks. Artikli esimeses osas esitame ülevaate teadusuuringutest ja teooriatest, mis käsitlevad professionaalset ja töökohal õppimist. Teises osas vaatleme töötamist nn õppe maastikul. See on metafoor, mida kasutame organisatsioonilise õppimise kirjeldamiseks. Kolmandas osas käsitleme õppimiseelistusi: kirjeldame viit töökohal õppimise viisi. Neljandas osas tutvustame õppiva professionaali kontseptsiooni. Viiendas osas anname ülevaate teadusuuringutest ja teooriatest, mis käsitlevad professionaalset identiteeti, mille lahutamatuteks osadeks on see, kes sa oled (inimesena), millist tööd (elukutse) ja kus sa seda teed (keskkond). Arutelu osas püüame selgitada, kuidas saab erinevaid mudeleid ühendada, diferentseerida ja lõimida. Kõikide käsitluste puhul lähtume professionaalsest identiteedist. Lõimitud kontseptuaalses küsimustikus võtame kogu teema kokku, pakume välja õppija identiteedi uue kontseptsiooni ja näitame, milliseid tulemusi annab professionaalse õppimiskultuuri soodustamine.
\end{abstract}

Märksõnad: professionaalne õppimine, professionaalne identiteet, õpikogukonnad, õppimise liigid, professionaalne õppimiskultuur, õppimiseelistused

\section{Sissejuhatus}

Professioone käsitlev uurimisvaldkond on väga mitmekesine. Kuid kas meie, teadlased, loome ka professioone käsitleva teooria? Nõustume Noliniga (2008), et „professionaalide kutsetegevuse kvaliteedi parandamiseks peaksid teadlased välja töötama professioonide definitsioonid ja standardid ning professioonide, professionaalse arengu ja professionalismi põhikontseptsioone käsitlevad teooriad“. Sellest lähtudes annab Nolin ülevaate valdkonna arengust, keskendudes mitte niivõrd selle eri etappidele, vaid pigem sellele, kuidas on teadlaste seisukohad professiooni ja professionalismi võtmekontseptsioonide käsitlemisel muutunud. Ta eristab professioonide uurimise kolme perioodi. Esimesel perioodil (1937-1970) peeti professioone valgustatuse väljenduseks ning nende osa ühiskonna moderniseerimisel ülioluliseks. Professioonid olid prestiižikad 
ja uurimistöödes keskenduti nende põhjalikult kirjeldatud tunnustele. Teisel perioodil (1960-1980) muutusid professioonid pigem domineerimise kui ühiskonna teenimise vahendiks. Üha enam elukutseid taotles tunnustamist ning sel ajal pingutati selle nimel, et luua professioonide, poolprofessioonide ja mitteprofessioonide hierarhia. Tähelepanu keskpunkt nihkus professiooni keeruliselt kontseptsioonilt professionaliseerumisele. Kolmandat perioodi (1980-?) iseloomustavad võimumängud, kus ametialade esindajates nähakse enese huvide eest võitlevaid ja üksteisega konkureerivaid huvirühmi. Sarnaselt mõne teisega (nt Freidson, 2001) teeb Nolin (2008) ettepaneku liikuda professioonide, professionaliseerumise ja professionalismi käsitlemise neljandasse faasi. „Kolmanda perioodi kriitilise ja distantseeritud uurimise asemel oleks palju kasulikum luua koostöös professionaalidega teoreetilised abivahendid, millest neil praktikas kasu oleks." (lk 45). Just selle poole me oma uurimuste ja praktikaga olemegi püüelnud. Oleme oma töös lähtunud viiest muudatusest, mida Nolin neljanda perioodi jaoks välja pakkus: a) rohkem tähelepanu professionaalide koolitamisele (tahaksime lisada: professionaalide õppimisele), b) selle asemel, et üritada võimuvõitlust mõista, otsida parem võimalusi selle suhtes midagi ette võtta, c) otsida koostöövõimalusi kutsealade sees ja vahel, d) muuta kultuuriline ja kutsealane mitmekesisus probleemi asemel väärtuseks ja e) teha kvalitatiivseid uuringuid.

Professionalismi (ehk professionaali põhiomaduste) käsitluse ajalugu analüüsides (Simons \& Ruijters, 2014) leidsime, et aja jooksul on suhtumises toimunud seitse pööret. Kunagi oli professionaaliks nimetamisel teatav negatiivne varjund, mõnel perioodil hinnati seda aga positiivselt. Olid ajad, mil professionaalideks peeti vaid üksikute erialade esindajaid (nt arstid, juristid), teinekord laiendati seda määratlust ka õdedele, õpetajatele, kunstnikele ja poliitikutele. Vahel loeti elukutselisteks inimesi, kes töötasid oma erialal raha eest, vastupidiselt neile, kes tegid seda lihtsalt lõbu pärast (amatöörid) või tasuta (härrasmeestest professionaalid). Oli perioode, mil professionaalsust seostati hea kvaliteediga, kuid oli ka aegu, kui seda peeti omamoodi negatiivseks hinnanguks, mis viitas kehvale kvaliteedile. Mitte alati ei ole peetud professionaali tiitlit positiivseks. Näiteks pakkus Hopkinsi ülikool kõrgema taseme kursusi vastandina (vähem väärtustatud) kutseõppele. Vahel peeti professionaalideks ülikooliharidusega kõrgelt haritud töötajaid, teinekord mitmekesise haridustaustaga oskustöölisi. Mõnel ajajärgul esindasid professionaalid võimu, teistel aegadel kuulusid nad pigem teenijate hulka. Kokkuvõttes leidsime, et eri aegadel on professionaalidele antud autonoomsus ja neile organisatsioonist lähtuvad piirangud väga tugevalt varieerunud.

Eespool loetletud seitset mõõdet kajastavad seisukohad ei ole muutunud mitte üksnes ajas, vaid erinevad ka kultuuriti ja rahvuseti. Juhime tähelepanu 
sellele, et meie teadusuuringute ja praktika toimumiskohaks oli Holland, kuigi lõimisime oma töösse ja teadusuuringutesse ka teistest riikidest ja rahvusvahelisest kirjandusest pärit vaatenurki. Praegu on professionalismil Hollandis valdavalt positiivne tähendus. Üha enam endiseid nn poolprofessionaale on nüüdseks ülendatud tõelisteks professionaalideks. Professionaalsus on peaaegu et hea kvaliteedi sünonüüm, see on ihaldatud aunimetus, misjuures (rakenduslikku) ülikooliharidust peetakse professionaaliks saamise eeltingimuseks, olgugi et selle tähtsus on vähenemas. Võimu dimensioon on säilinud, kuid see ei ole enam nii oluline. Kutsealade vahelist koostööd ja kollektiivset professionalismi peetakse tähtsaks. Siiski kurdavad mõned professionaalid, et rangete kontrollimehhanismide tõttu ei ole neil organisatsioonis piisavalt mõjujõudu. Samas räägitakse palju professionaalide tegutsemisvabaduse laiendamisest, pakkudes neile võimalusi professionaalseks arenguks.

Siinses artiklis püüame teha kokkuvõtet oma tööst, mida oleme teinud professionaalide uurimisel, ning pakkuda välja professionaalse õppimise lõimitud mudeli (individuaalne ja kollektiivne), milles on seostatud järgmised kontseptsioonid: õppimine, professionalism, õppimiseelistused, organisatsiooniline õppimine, professionaalne identiteet ja professionaalne õppimiskultuur.

Sajandi alguses töötasime välja esimese professionaalse õppimise mudeli (Simons \& Ruijters, 2001; 2004). Aja jooksul oleme seda mudelit arendanud kolmes suunas - professionalism, õppimine ja identiteet - ja viies etapis:

1) Professionaalse õppimise mudeli loomine.

2) Professionaalse õppimise mudeli muutmine üldisemaks organisatsioonide õppemaastike mudeliks (Simons \& Ruijters, 2001; Ruijters, 2006; Ruijters \& Simons, 2006).

3) Õppimiseelistuste mudeli lisandumine (Ruijters, 2006; Simons \& Ruijters, 2008).

4) Professionaalse õppimise käsitluse nihkumine õppiva professionaali kontseptsiooni suunas (Simons \& Ruijters, 2014; Ruijters \& Simons, 2015).

5) Õppiva professionaali käsitluse ühendamine professionaalse identiteedi käsitlusega (Ruijters, 2015a; Van Oeffelt, Ruijters, Van Hees, \& Simons, 2017).

Siin artiklis püüame lõimida need mudelid üheks töökohal õppimise ja professionaalse õppimise mudeliks, võttes kasutusele uued õppija identiteedi ja professionaalse õppimiskultuuri kontseptsioonid. Meie lähenemisviisi viis etappi ja neid tutvustavad artiklid pälvisid Hollandis ja mõnes teises riigis (Belgias, Eestis, Saksamaal ja Rootsis) suurt tähelepanu. Meilt küsiti pidevalt nende mudelite omavahelise suhestumise kohta. Püüame oma artiklis neile küsimustele vastata. 
a) Millised on erinevused meie esialgsete ja hilisemate professionaalset ja töökohal õppimist käsitlevate mudelite vahel?

b) Kuidas sobituvad õppimiseelistused meie õppemaastikule?

c) Kuidas on omavahel seotud professionaalne identiteet ja professionaalne óppimine?

d) Milline võiks olla terviklik ühendmudel?

e) Mida tähendab see professionaalse õppimiskultuuri jaoks?

Ühendades oma varasemad tööd üheks tervikuks, pakume välja kontseptuaalse küsimustiku, mis aitab õppijatel analüüsida oma õppija identiteeti ehk seda, kes nad on professionaalsete õppijatena. Kõik see sobib kokku Nolini (2008) neljanda etapiga, mida on kirjeldatud eespool.

\section{Uurimismeetod}

Sellesse artiklisse oleme koondanud varem mitmes raamatus ja ajakirjas nii inglise kui ka hollandi keeles avaldatud ideid ja mudeleid. Igast artiklist valisime välja kõige olulisemad kontseptsioonid ja mudelid. Kuigi viis õppimise mudelit on selle artikli autorite loodud, ei ole need veel lõimitud ühtseks õpikäsituseks. Pealegi ei ole me mudelite erinevusi ja kattuvusi siiani põhjalikult käsitlenud.

Selle artikli aluseks olnud originaalartiklites on kasutatud mitut metoodikat. Mõned meetodid pärinevad meie doktorantide uuringutest, kes avaldasid empiirilisi kvalitatiivseid uuringuid, mida me ühistes artiklites kasutasime. Mõne artikli aluseks võeti kirjanduse ülevaade, teistes olemasolevad teoreetilised mudelid, mida arendati või muudeti. Vahel kasutati professionaalidega tehtud intervjuudel põhinevaid uuringuid. Siinne artikkel on oma olemuselt kontseptuaalne.

Eri kontseptsioonide loomisel kasutati allpool kirjeldatud meetodeid. Kaks esimest mudelit (professionaalne õppimine ja töökohal õppimine) olid kontseptuaalsed. Need kasvasid järk-järgult välja kirjandusest leitud lähenemisviiside ümbersõnastamisest ja lõimimisest, mis toimus professionaalse tegevuse, doktorantide uurimistööde (nt Berings, 2006; Doornbos, 2006) ja magistritaseme üliõpilaste õpetamise käigus. Neile toetuti teadusuuringute järgmistes etappides.

Õppemaastiku mudeli töötas Ruijters (2006) välja oma doktoriõppes koostatud uurimuses. Maastikumudeli esimene versioon oli töökohal õppimise mudeli metafooriline laiendus. Eri õppimisviise kujutati kui organisatsiooni tasandil toimivaid saari, sildu ja poldreid. Ruijters (2006) kasutas seda kontseptsiooni organisatsioonilise õppimise uurimiseks, et mõista, kuidas käsitlevad 
organisatsioonid õppimist. Tegevusuuringutel, mis korraldati hoolekande- ja raviasutustes, konsultatsioonifirmades, valitsusasutustes, politseis ja tuletõrjes ning hiljuti ka säästvale arengule üleminekul, kasutati maastikumudelit diagnostilise vahendina ja arendati seda töö käigus edasi. Kolmest peamisest tegevusest ammutati väärtuslikke kogemusi: kollektiivsete õppimismustrite kavandamine, õppimist võimaldavate sekkumiste kavandamine ja sekkumistele järgnev mõju hindamine organisatsioonis.

Õppimiseelistusi uuriti 65 küsimusest koosneva küsimustikuga. Küsimustik sisaldas 15 põhiküsimust, näiteks: a) olukorrad, milles õpitakse; b) õppimine koos teistega; c) tegelemine vigadega. Iga põhiküsimuse kohta esitati vastavalt viiele võimalikule eelistusele neli või viis täpsustavat küsimust. Näiteks põhiküsimuse „Mis sind õppimisolukorras närvi ajab?" viis võimalikku vastust olid: a) See, kui on igav; b) See, kui meeskonnaliikmed end meeskonnast taandavad; c) Kui teistel inimestel pole piisavalt teadmisi; d) Kui tunnen end ebakompetentsena; e) Kui kõik on ette kindlaks määratud. Iga 65 alaküsimuse puhul pidid vastajad andma vastuse viiepalliskaalal, mille üks ots tähistas üldse mitte meeldivat ja teine väga meeldivat. Esialgses uuringus katsetati äsja valminud küsimustikku 713 algkooliõpetaja, 92 algkoolidirektori ja 33 tugiisiku peal. Vastustest koorus välja viis kindlat õppimiseelistust ja selgus, et need osutusid usaldusväärseteks, kuigi mõningane küsimuste täiustamine osutus vajalikuks. Skaaladevaheline korrelatsioon osutus ootuspäraseks. Haridussüsteemi, vanust, kogemust ja haridustaset kajastavates muutujates leiti tähenduslikke seoseid. Teise uuringu käigus katsetati täiustatud küsimustikku 12 organisatsioonis töötanud 556 professionaali peal.

Õppiva professionaali mudel loodi professionalismi ja selle ajaloolist arengut käsitleva kirjanduse süstemaatilise ülevaate põhjal. Lähtepunktiks võeti Gardneri ja Shulmani loodud käsitlus. Teaduskirjandusest leitud ja välja valitud 15 artiklit kasutati Gardneri ja Shulmani käsitluse kontrollimiseks, vastuväidete leidmiseks ning nende teooria laiendamiseks.

Ruijters (2015b) alustas 2012. aastal ulatuslikku professionaalse identiteedi uurimise projekti. Ruijters ja tema kolleegid intervjueerisid 47 professionaali, et uurida nende arusaamu professionaalsest identiteedist. Esitati näiteks järgmisi küsimusi: kes on teie jaoks professionaal? Kuidas on teie professionaalsus aja jooksul arenenud? Kuidas on teie professionaalsus seotud teie isikliku ja sotsiaalse arenguga? Kuidas on teie professionalism seotud teie organisatsiooni ja ametitega? Intervjuudega kogutud andmed transkribeeriti ja neid analüüsiti telgkodeerimise teel. Ühe meetodina kasutasime ka eri mudelite kontseptuaalset lõimimist. Otsisime kattumist, erinevusi, laiendusi ja eelkõige seoseid eri käsitlusviiside vahel ning vastuseid eespool loetletud küsimustele. 


\section{1. etapp: erialaõpe ja töökohal õppimine}

Varasemates töödes alustasime sellest, et defineerisime professioone kui tegevusalasid, mis nõuavad käsiraamatutes ja ametlikes (teaduslikes) väljaannetes kirjeldatud kindlaid teadmisi ja mille jaoks on kehtestatud kvaliteedinõuded ja loodud kutseliidud (Greenwood, 1957; Thijssen, 1987). Professionaalid on ametiala valdavad erilist tüüpi töötajad. Kutseliidud koondavad professionaale, kehtestavad kvaliteedistandardeid, aitavad arendada nende teadmisi ning sertifitseerivad õpitulemuste kvaliteeti tagavat haridust ja koolitust. Professionaaliks peetakse isikut, kes töötab kindlal kutsealal, kellel on selge visioon, kes kasutab spetsifilist metoodikat ning kvaliteetseid tööriistu ja tehnikaid. Oma praktikast lähtudes ja inspireerituna teiste teoreetikute töödest leppisime kolleegide ja tudengitega kokku, et professionaal peab tegema kolme asja: praktiseerima valitud erialal, olema seotud teadustööga või seda ise tegema ning teisi õpetama. 1) Professionaal saab olla ja selleks jääda vaid siis, kui tal on praktiline töökogemus klientidega. Arsti puhul tähendab see töötamist patsientidega, juhi puhul töötajatega. 2) Professionaal peab olema seotud oma valdkonnas tehtavate teadusuuringutega. 3) Professionaalil on kohustus edastada oma töökogemusi teistele ja edendada kutsealast asjatundlikkust oma valdkonnas.

Sellest lähtudes lisasime professionaalide ja poolprofessionaalide töökohal õppimist käsitlevatesse uurimustesse ka õppimiskogemuste aspekti. Nii et esiteks ei ole oluline mitte ainult praktiseerimine, vaid ka õppimine töötamise käigus ja selle kaudu. Teisisõnu, professionaal peab olema võimeline kogemustest õppima. Teiseks ei ole oluline vaid see, et ollakse teadustööga seotud või sellesse kaasatud, oluline on sellest ka õppida. Seetõttu oleme õppimise etapid ümber defineerinud ning välja toonud kolm õppimise viisi: kriitiline, uuriv ja teoreetiline (Bolhuis, 1996). Kolmandaks on oluline õppimine teiste õpetamise kaudu. See aitab professioonil areneda ja professionaalil õppida. Seda saab teha õpetamise kaudu, kuid ka raamatute ja artiklite kirjutamise, juhendamise, konverentsidel ettekannete pidamise, õppevahendite väljatöötamise, teiste professionaalidega arutelude ja muu sarnase kaudu. Meie arvates võib välisesse professionaalsesse keskkonda panustada ka meeskonna või organisatsiooni tasandil.

Seega õpivad professionaalid kolmel üksteisega osalt kattuval viisil:

1) selginemine: oma tööalase pädevuse suurendamine, õppides teiste ja enda kogemustest;

2) avardumine: oma teoreetiliste teadmiste täiendamine, õppides teiste teadustööst ja seda ise tehes;

3) arendamine: oma praktiliste ja teoreetiliste teadmiste abil kutseala ja/või meeskonna ja organisatsiooni arengu toetamine. 
2004. aastal kirjutasime artikli (Simons \& Ruijters, 2004), mis viis meie käsitluse järgmisele tasemele ehk professionaalide õppimiselt õppivate professionaalide kontseptsioonini. Seda tehes defineerisime ümber, keda me praegu professionaaliks peame. Professionaaliks ei peeta enam vaid hea hariduse ja kutseliidult heakskiidu saanud isikut, vaid inimest, kes on valmis pidama õppimist keskseks osaks oma töös ja mõistab, et omal alal meistriks saamine ei lõppe hea hariduse omandamisega. Ühtlasi tähendas sellisele arusaamale jõudmine, et enam ei omistanud me professionaali mõistet vaid professioonidele, millel on kutseliit. Meie seisukohalt tähistas professionalism teatud vaimsust, isegi nende puhul, keda traditsiooniliselt professionaalideks ei peeta (näiteks juhid, õed, sekretärid ja õpetajad).

\section{2. etapp: õppemaastikud}

Töökohal õppimise mudeli praktiline rakendamine organisatsiooni arengu ja õppimise hüvanguks aitas meil mõista, et praktikas ei käitunud kolm töökohal õppimise viisi (selginemine, avardumine ja arendamine) mitte kattuvate väljade, vaid pigem eraldatud saartena. Sellest sai alguse mõtlemine metafooride abil. Kui sellised óppimise viisid olid saared organisatsioonide sees, siis mis neid saari ühendas?

2006. aastal avaldatud artiklis (Ruijters ja Simons, 2006) analüüsisime ja kirjeldasime neid kolme põhilist õppimisviisi, kasutades õppimise saarte metafoori. Õppemaastik koosneb kolmest saarest ehk õppimisviisist: õppimine praktiseerimise, uurimise ja loomise kaudu. Õppemaastiku ülejäänud osad olid sillad ja poldrid (vt joonist 1). Sillad loovad ühendusi saarte saavutatud tulemuste vahel. Poldrid ühendavad saari uue maa tekkimise teel. Merest saadud maad nimetatakse poldriks. See on Hollandi jaoks väga oluline kontseptsioon, mis tähendab uue maa loomist merest.

\section{Saared}

Praktiseerimise alla kuulub kogu õppimine, mis toimub (enamasti) automaatselt nii töötamise, probleemide lahendamise kui ka elamise käigus. See on õppimine muude tegevuste kõrvalmõjuna ning seda ei ole enamasti varem korraldatud, planeeritud ega struktureeritud. Selle tulemusena tekivad kogemuslikud teadmised ja oskused.

Uurimine hõlmab sellist õppimist, mis viib uute (enamasti põhjalike) teadmiste ja oskusteni. See hõlmab teadusuuringutes osalemist või seotust nendega, samuti raamatute ja ajakirjade lugemist, konverentsidel käimist, praktiliste või rakendusuuringute tegemist, arutelude pidamist, uurimisvõimaluste võrdlemist. 
Loomine viitab õppimisele, mis toimub uute töövahendite, toodete, trükiste või teenuste arendamise kaudu. Eri loomisviisid viivad disainimisoskuste omandamiseni. Sellised teadmised tekivad juhul, kui arendamise või loomise käigus saadakse teadlikuks oma teadmistest ja eriti sellest, mida veel ei teata.

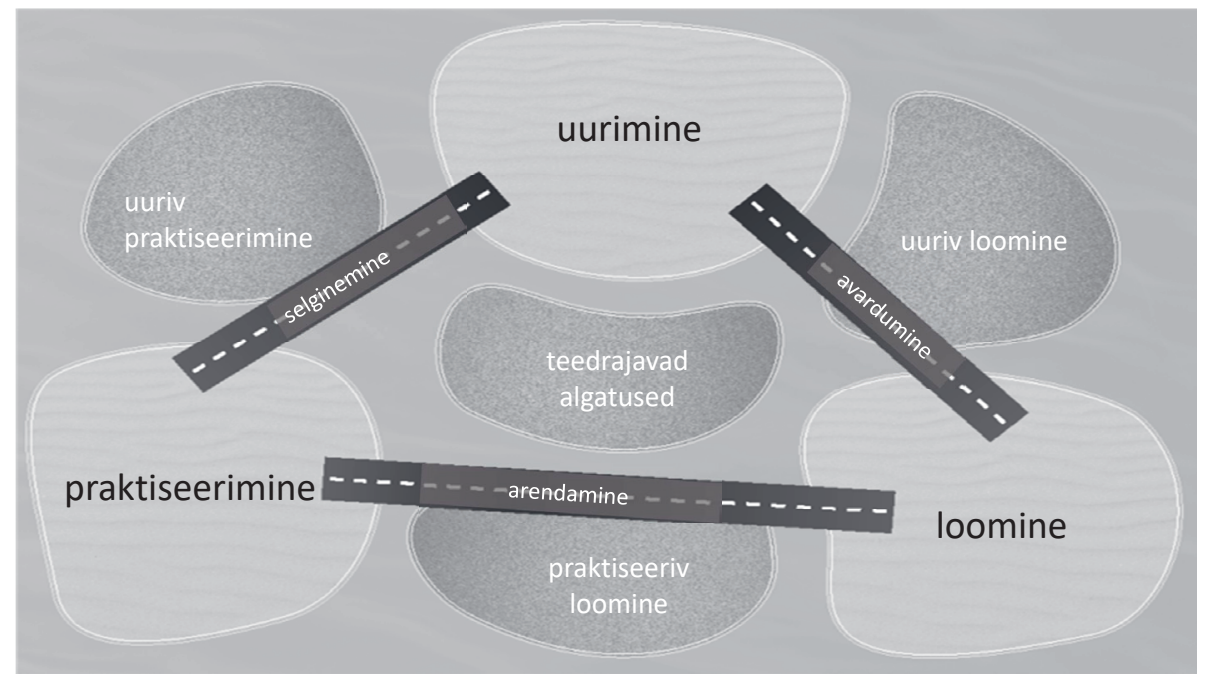

Joonis 1. Õppemaastiku metafoor (Ruijters \& Simons, 2006).

\section{Sillad}

Praktiseerimine, uurimine ja loomine on õppemaastiku mudeli kolm põhikomponenti. Samas ei ole need õppimise viisid automaatselt omavahel seotud. Just nagu saared meres, kipuvad nad olema eraldi. Praktiseerimise käigus õpitu erineb sellest, mida õpitakse uurimise või loomise kaudu. Sillad lisati saari ühendavate õppimisviiside paremaks visualiseerimiseks. Saarte ühendamine on oluline mitmel põhjusel: need aitavad keskenduda inimese professionaalsele arengule, näiteks otsitakse uusi teadmisi selleks, et vastata praktika käigus tekkinud küsimustele. Nii antakse kogemustele selge sõnastus, et neid oleks parem teistega jagada, ning luuakse mõningane distants praktikaga, mis võimaldab näha väljakujunenud mustreid ja kasutada kahesilmuselist õppimist ${ }^{1}$, kui nimetada vaid mõningaid.

\footnotetext{
Kahesilmuselise õppimise mõiste pärineb õppiva organisatsiooni teooriatest. Selle järgi on õppivad organisatsioonid võimelised perioodiliselt ümber hindama oma eesmärke ja väljakujunenud praktikaid ja norme ning neid vajaduse korral muutma. Õppimine toimub kahes etapis: algul tegutsetakse olemasolevate normide järgi ja kui need ei tööta nagu vaja, siis õpitakse oma kogemusest ja muudetakse vajaduse korral ka oma väärtusi ja suhtumisi. Vt Argyris, Chris (May 1991). „Teaching smart people how to learn“ (PDF). Harvard Business Review. 69 (3): 99-109. - Toim.
} 
Sildade kaudu on ühe õppimisviisi (st praktiseerimise, uurimise või loomise) tulemused ühendatud teiste õppimisviisidega. Praktiseerimise ja uurimise vahelist silda nimetame selginemiseks: kaudsete teadmiste kogumine, mis saadakse otseselt praktiseerimise kaudu ja mida on võimalik edasi uurida ja seejärel rakendada praktikas kui otseseid teadmisi. Selginemise sillal vastassuunas liikudes viiakse uurimise teel saadud teadmised praktikasse. Uurimise ja loomise vahelist silda nimetame avardumiseks. See sild ühendab uusi teadmisi võimalike toodete, vahendite või teenustega, mida saab selle teadmise põhjal edasi arendada, ja näitab, mis on piisavalt huvitav, ning aitab leida olulisi sihtrühmi ja turgusid. Vastassuunas liikudes on võimalik täita lünki teadmistes, mille abil planeerida, arendada või avaldada. Kolmandat silda nimetatakse arendamiseks ning see ühendab uusi tooteid, teenuseid, tööriistu ja teadusuuringuid praktikaga ehk näitab, kuidas praktikas uusi ideid ellu viia ja milliseid uusi tooteid või vahendeid praktikas vajatakse. Sildu võib ületada mõlemas suunas.

\section{Poldrid}

Seni kirjeldasime kolme põhilist õppimise viisi (praktiseerimine, uurimine, loomine) kui kolme saart. Isetekkelisi ühendusi nende saarte vahel ei ole, kuid professionaalseks arenguks on neid tarvis. Töökeskkonnas on kõiki õppimise viise võimalik korraldada nii individuaalselt kui ka koostöös teistega: kolleegide, juhendajate, juhtide ja klientidega. Kõik osalejad võivad kaudsesse õppimisse tuua eri vaatenurki ja seda täiendada.

Saartevaheliste kollektiivsete ühenduste puhul kasutame terminit polder. See on uus maa saarte vahel. Kahel saarel õppimise protsessid on lõimitud kollektiivsesse õppimisprotsessi. Professionaalide ühine eesmärk on kahel või kolmel saarel toimuvad õppeprotsessid omavahel ühendada.

Esimene polder praktika ja uurimise vahel on oma praktika uurimine. Praktikud uurivad oma tegevust, tehes seda üldjuhul koos. Teisel poldril (uurimise ja loomise vahel) kombineeritakse loomist ja uuringuid ning need segunevad omavahel. Uued tooted või teenused töötatakse välja vaheldumisi uurides ja disainides. See on innovatsiooni tekkeks vajalik polder. Kolmas polder tekib praktiseerimise ja loomise vahele: praktiseerimine ja loomine on ühiskondlikul tasandil põimunud. Selle abil täiustatakse praktikat ja juurutatakse uusi töövõtteid. Pooleldi valminud tooted võimaldavad praktikutel töötada disaineritena ja koos disaineritega, et sobitada tooteid oma keskkonnaga. Meie mudeli neljas poldrikomponent paikneb keskel ja kasutab ära kõiki kolme saart. See on seotud praktika ümberkujundamisega, luues ruumi eeluuringutele ja eksperimenteerimisele, alustades tühjalt kohalt. Varem ei ole võimalik 
kindlaks teha, milline suund tuleks võtta. Teerajajatena algatavad praktikud katseprojekte ja loovad prototüüpe, kombineerides praktikat, teadusuuringuid ja loomist. Poldrid ja saared paiknevad meres, mis esindab transformatiivset õppimist, olles teadlik täiesti uue mõtteviisi vajalikkusest.

Õppemaastiku metafoori on kasutatud diagnostikavahendina, mis aitab organisatsioonidel välja selgitada, kuidas nende õppimisega seotud sekkumised omavahel kokku sobivad (või mitte) ja seatud eesmärke täidavad. Nüüdseks on seda metafoori palju kordi kasutatud ka sekkumiste kava koostamisel või olemasolevate sekkumiskavade ümberkujundamisel. Selle abil on organisatsioonidel lihtsam aru saada, kus on vaja ühisloomingut või eri kontekstides õppimise ülekandmist sildade kaudu.

\section{3. etapp: õppimiseelistused}

Selleks et mõista ja kirjeldada professionaalidelt õppimise mitmekesisust, otsustasime uurida, milline mitmekesisus on õppimisele üldiselt iseloomulik.

Tuginedes Manon Ruijtersi doktoriväitekirjale (2006), eristasime ja testisime viit õppimisviisi ehk õppimiseelistust. Oma uuringutes (Ruijters, 2006; Simons \& Ruijters, 2008) oleme analüüsinud kattuvaid eelistuste mustreid, mis kujunevad aja ja karjääri jooksul ning mida on võimalik õppida. Kahjuks kipuvad praktikud kasutama neid siiski õpistiilidena.

Kirjanduse põhjal tuletasime järgmised viis õppimiseelistust. Oma artiklis õppimise kahe metafoori kohta kirjeldas Sfard (1998) esmakordselt erinevust kahe õppimiseelistuse, omandamise ja osalemise vahel. Omandamiseelistuse kohaselt käsitletakse teadmist maailma kohta objektiivse tõena, mida saab ühelt inimeselt teisele edasi anda (Bruner, 1996).

Osalemiseelistuse puhul eeldatakse aga järgmist (Sfard, 1998): a) objektiivset tõde ei ole olemas ja teadmised konstrueeritakse inimestevahelises sotsiaalses suhtlemises; b) õppimisega peavad inimesed ise tegelema; neid on võimalik selles küll aidata, kuid keegi teine ei saa seda nende eest teha; c) õppimine toimub järk-järgult praktiseeriva kogukonna (või kultuuri, professiooni või teadusvaldkonna) liikmeks saamise teel; see toimub peamiselt väljaspool institutsioone ning selles mängivad olulist osa vaikivad teadmised ja oskused.

Paavola, Lipponen ja Hakkarainen (2002) on veenvalt näidanud, et omandamiseelistuse ja osalemiseelistuse vahele jäävat lõhet võiks täita kolmanda ehk avastamiseelistusega. Nad tuginevad Engeströmi (1999), Bereiteri (2002) ning Nonaka ja Takeuchi (1995) loodud kolme teadmusloome teooria analüüsile.

Neljandat eelistust (tajumine ehk vaatlemine ja imiteerimine) tutvustatakse eelkõige juhtimisalast koolitust käsitlevas kirjanduses. Meggison (1996) 
nimetas seda ilmutuslikuks õppimiseks. See on õppimine, mida ei ole kavandatud. Veelgi enam, seda ei peeta üldse õppimiseks. Sellist õppimist kirjeldab võib-olla kõige paremini väljend "hetke ajend“, mis tekib siis, kui murtakse pead väga keerulise ülesande kallal, vaadatakse ringi, otsitakse toimivaid lahendusi, samas neid analüüsides ja kopeerides.

Teoreetiliselt seondub selline õppimisviis paljuski Bandura (1986) sotsiaalse õppimise teooriaga, mis keskendub õppimisele vaatlemise, imiteerimise ja modelleerimise teel.

Viimane, viies õppimiseelistus põhineb Ericssoni mõtestatud harjutamise teoorial (Ericsson, Krampe, \& Tesch-Romer, 1993). See teooria kirjeldab, kuidas muusikud, sportlased ja oskustöölised harjutavad regulaarselt, et saavutada paremaid tulemusi või suurendada oma pädevust. Viies õppimiseelistus, mida meie nimetame harjutamiseelistuseks, põhineb seega õppimisvõimel. Siin on õppija aktiivses rollis, õppides teadlikult koostöös teistega, et pidevalt õppivas organisatsioonis oma taset hoida. Selliseks õppimiseks on vaja asjatundjate juhiseid, koostööd teistega ja turvalist keskkonda.

Allpool kirjeldame lühidalt viit õppimiseelistust.

\section{Mõtestatud tajumine (imiteerimine ja vaatlus)}

Õppijad, kes eelistavad mõtestatud tajumist, proovivad leida konkreetse valdkonna eksperte ning õpivad, jälgides tähelepanelikult praktikas edukaid inimesi ja järgides nende eeskuju. Sel viisil õppijad armastavad lugusid ja näiteid parimatest töövõtetest ja tahavad teada, mis töötab. Samas ei meeldi neile rollimängud ja harjutused, mida nad peavad pigem lapsikuks. Neile on oluline õpisituatsioonide realistlikkus ja parajat väljakutset pakkuvate ülesannete lahendamine, kus on oluline vigade vältimine ja nõrkuste pööramine tugevusteks.

\section{Osalemine}

Osalemist eelistavatele inimestele meeldib õppida koos teistega. Rõhutatakse õppimise sotsiaalset poolt: õpime koos ja üksteiselt. Nende arvates ei ole olemas objektiivset teadmist, vaid igaühel on oma tõlgendus sellest ning teistega suheldes on võimalik jõuda ühise arusaamani. Osalemist eelistavad inimesed õpivad suhtlemise kaudu. Suhtlemine on nende jaoks oluline. Nad vajavad elavat ja avatud diskussiooni oma ideede lihvimiseks ja selgitamiseks, mis omakorda soodustab tagasisidet teistelt kas reaktsioonide või ideede näol. Selliste õppijate jaoks on õppimine kõige lihtsam rühmas, mille liikmed on üksteisest huvitatud ja usaldavad üksteist. Sellisel viisil õppimine on tõhusam, kui rühmas õppides on kellelgi rühmajuhi roll, kuid kasu võib olla ka rollide järgemööda vahetamisest. 


\section{Omandamine}

Omandavad õppijad omistavad suurt tähtsust teadmiste edasiandmisele ja oskuste õppimisele. Enamasti õpivad nad hästi, kui eesmärgid on paigas ja õppeprotsess kindlaks määratud. Neile meeldib, kui neid õpetavad eksperdid, õpetajad, kes tunnevad oma ainet hästi. Lõpuks on teadmised objektiivsed ja oluline on omandada teadmisi rikkumata keskkonnas. Omandamise puhul on vigade tegemine taunitud: vigade tegemine viitab puudustele õppeprotsessi planeerimisel, lohakale ettevalmistusele või ebapiisavatele teadmistele. Sellised õppijad teavad, mida nad õppida tahavad, ja suunavad oma õppimise konkreetse tulemuse saavutamisele. Regulaarne testimine on osa sellest õppeprotsessist, lõppude lõpuks saab ju teadmisi mõõta. Eksamitulemused näitavad täpselt, kui palju loodetud tulemustest on saavutatud.

\section{Harjutamine}

Harjutamisel korratakse sama tegevust ikka uuesti ja uuesti töötamisega võimalikult sarnases situatsioonis, kasutades selliseid õppimise vorme nagu väljaõpe töökohal, töökogemustest õppimine ja rollimängud. Kõige olulisem on see, et õpitut oleks võimalik praktikas rakendada. Seetõttu toimub õppimine reaalsusega võimalikult sarnastes oludes. Selle lähenemise tuumaks on see, et tagatakse n-ö õppimisolukord. See tähendab, et keskkond peab tunduma piisavalt turvaline, et õppija julgeks teha vigu. Keskkond peaks olema ka piisavalt korrastatud, et õppija saaks keskenduda tegevustele, mis aitavad tal seatud eesmärke saavutada.

\section{Avastamine}

Õppimine kui avastamine viitab arusaamale, et me õpime kogu aeg väga erinevates igapäevastes situatsioonides, mitte ainult koolitundide või kursuste käigus. Ei ole olemas olukorda, mis meid ei õpetaks. Õppimine tähendab olukordade mõistmist ja nendega hakkamasaamist. Sellest teadlik olemine õpetab meile palju igapäevaelu ja ootamatute sündmuste kohta, millega meil kokku tuleb puutuda. Selline õppimine eeldab suurt vabadust, sest sellised õppijad eelistavad käia mööda enda valitud teed. Valitud tee ei pruugi olla kõige tõhusam, kuid on tähtis, et see oleks kõige huvitavam. Sellised õppijad otsivad ja leiavad inspiratsiooni ja tähendusrikkust end ümbritsevast keskkonnast, sõpradest ja inimestest enda ümber.

Nüüdseks oleme kogunud digitaalselt ja paberkandjal tehtud 65 uuringu kaudu üle 40000 õppimiseelistuse (ei ole veel avaldatud). Uuringute tulemusena on alati jõutud kattuvate eelistuste mustriteni. Enamasti eelistavad 
inimesed kahte või kolme õppimisviisi ja neil on mõningane huvi veel ühe vastu viiest. Eelistusi ei tajuta stabiilsete õpistiilidena, vaid ajutiste eelistustena. Kasutasime tuvastatud mustreid oma praktikas mitmel viisil: üksteise tundmaõppimiseks, koolituse ja õpetamise häälestamiseks vastavalt suurema osa õppijate õppimiseelistustele, óppijate rühmade eristamiseks ja eri lähenemisviiside tundmaõppimiseks.

Praktikas õppimiseelistustega kokku puutudes, näiteks töötades kohtunike ja ettevõtjatega, saime teada, et lisaks meie algsele viiele õppimiseelistusele on veel kaks: intuitiivne õppimine ja kujutlev õppimine. Intuitiivne õppimine hõlmab õppimist ühiskondlikult kõrge positsiooniga kaasnevates keerulistes olukordades ja algab ulatuslikust info, teadmiste ja arvamuste kogumisest, millele järgneb intuitsioonil põhinev tunne (kõhutunne), et teatud lahendus või otsus on just see õige. Õppimine on midagi enamat kui kontrollimine ja testimine, tõendite ja neid ümber lükkavate tõendite otsimine. Mõned meie kliendid ei pea seda õppimiseks, aga meie peame. Kujutlev õppimine on omamoodi elava kujutluspildi loomine sündmustest enne, kui need toimuvad. Enne kohtuistungit ja selle käigus loovad kohtunikud toimuma hakkavast elava kujutluspildi, valmistavad end selleks ette, kaaludes sisemiselt (kujutledes vaimusilmas), milliseid võimalusi võivad osalejad kasutada ja kuidas neile reageerida. Õppimine toimub kontrollides, millised stsenaariumid lähevad täide ja kas kõikidele stsenaariumidele sai ikka enne mõeldud. Mõlemad õppimisviisid tuginevad suurtele kogemustele eriliselt keeruliste olukordadega hakkama saamisel. Siin on väga oluline roll intuitiivsetel ja automatiseeritud teadmistel.

\section{4. etapp: õppiv professionaal}

2014. aastal ilmunud artiklis (Simons \& Ruijters, 2014) esitasime ulatusliku kirjanduse ülevaate, otsides aegade jooksul toimunud muutusi professionalismi kontseptsioonis. Püüdsime leida professionaalide põhiomaduste kirjeldusi ka rahvusvahelistest väljaannetest. Võtsime lähtepunktiks Gardneri ja Shulmani (2005) artikli. Nemad on esitanud kuus professionaale kirjeldavat omadust.

Kirjanduse läbitöötamine kinnitas enamikku Gardneri ja Shulmani (2005) põhimõtteid, kuid avastasime ka mõningaid erinevusi ja edasiarendusi. Lisaks leidsime kirjandusest ka mõned nende käsitlusest välja jäänud põhimõtted. Enamgi veel, panime tähele, et nende puhul olid tööga seotud põhimõtted õppimisega seotutega segunenud. See viis professionaalide tööd iseloomustava kaheksa tunnuse loomiseni ja ettepanekuni iseloomustada professionaalide õppimist kaheksa paralleelse tunnuse abil.

Pakkusime professionaali kirjeldamiseks välja järgmised kaheksa omadust (Simons \& Ruijters, 2014). 
a) Pühendumus: nad on pühendunud klientide ja ühiskonna teenimisele.

b) Ausameelsus: neil on tahe ja võime tunnistada, kui nad mõnda asja ei tea või kui mõni olukord on nende jaoks ootamatu.

c) Laialdased teadmised: neil on abstraktsed teadmised (teadmiste kogum), mida nad on valmis ja võimelised praktikas kasutama, ning nad jälgivad teaduse arengut.

d) Tegevusteooria: neil on piisavalt erialaseid oskusi ja nad tunnevad eri tegevusteooriaid.

e) Pädevusvaldkond: neil on oma kutsealal kindel pädevusvaldkond.

f) Professionaalne kogukond: nad kuuluvad ühte või mitmesse professionaalsesse kogukonda, neil on kalduvus töötada kollektiivselt ja valdkonnaüleselt, et keerukate ülesannetega toime tulla.

g) Autonoomsus: nad juhivad ennast ise ja otsustavad iseseisvalt, mida teha, lähtudes oma professionaalsusest (selle tulemusena, mitte selle pärast, et nõutakse).

h) Autoriteet: teatud tingimustel peetakse neid oma valdkonna asjatundjateks; professionaali arvamust peetakse pädevamaks kui mitteprofessionaali oma.

Need põhimõtted koostati kirjanduse põhjal, kombineerides neid Gardneri ja Shulmani artikliga. Otsustasime, et pühendumus ja ausameelsus on nõuded, järgmised neli olid omadused ja kahte viimast nimetasime hüvedeks (vt joonist 2).

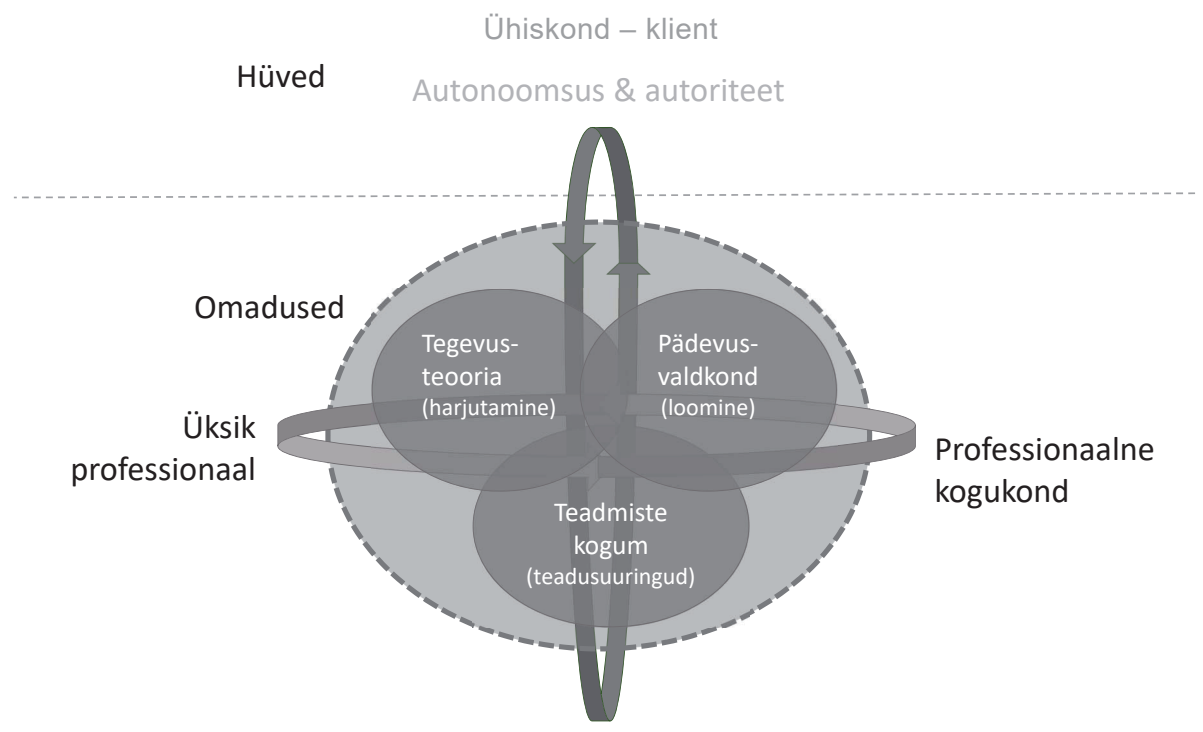

Nõuded Pühendumus \& ausameelsus

Joonis 2. Professionaali kaheksa omadust. 
Jõudsime järeldusele, et professionaaliks olemine on valik, mitte hariduse või ametijuhendiga kaasnev staatus. Professionaaliks jäämise valimine nõuab nende kaheksa omaduse pidevat täiustamist. Neilt kaheksalt omaduselt liikusime edasi sellele, kuidas professionaalid õpivad, ehk teisisõnu jõudsime õppiva professionaali omadusteni (Simons \& Ruijters, 2014). Osalt pärinesid need Gardnerilt ja Shulmanilt (2005), osalt kirjandusest ja osaliselt põhinesid need eespool kirjeldatud kaheksal professionalismi kirjeldaval omadusel. Seega õppivad professionaalid:

a) pühenduvad tõeliselt õppimisele ja enese arendamisele;

b) on valmis mõtisklema kogemuste üle olukordadest, kus neil jäi teadmisi puudu või mis olid ootamatud;

c) ammutavad teadmisi teooriatest ja teadustööst;

d) soovivad ja suudavad olla reflekteerivad praktikud, kes omandavad uusi teadmisi praktika kaudu;

e) suurendavad pidevalt oma eriteadmisi ja töötavad oma pädevusvaldkonnas;

f) kuuluvad ühte või mitmesse professionaalsesse kogukonda, neil on kalduvus töötada kollektiivselt ja valdkonnaüleselt, et keerukate ülesannetega toime tulla;

g) eelistavad ennast ise juhtida ning töötada ja õppida autonoomselt. Professionaalid teevad ise valiku olla professionaalid ja seega töötavad ja õpivad iseseisvalt;

h) on motiveeritud kujundama oma professiooni ning koolitama teisi professionaale ja algajaid. Selle kaudu tugevdavad nad oma autoriteeti.

\section{5. etapp: professionaalne identiteet}

Viimastel aastatel oleme pidanud vajalikuks lisada veel ühe punkti mõttevahetusse professionaalide ja õppimise teemal. See sai alguse mõttest, et vaid piiratud osa organisatsioonides toimuvast õppetööst täiendab või suurendab teadmisi. Üha sagedamini on see seotud hoopis muudatuste tegemisega töökorralduses või töö täieliku ümberkorraldamisega. Professionaalne identiteet omandab üha suuremat tähtsust. Enamiku inimeste jaoks tähendab õppimine ja areng siiski pidevat teadmiste suurendamist ning oskuste täiendamist. Harva hakkame äsja omandatud ideid ümber kujundama (Illeris, 2014; Kegan, 2009). Pöörame vähe tähelepanu sellele, kas õpitu sisu vastab inimese vajadustele. Näiteks jätame küsimata sellised küsimused nagu „Mida teadmised sulle tegelikult tähendavad?“, „Kuidas see sobib kokku sinu olemuse ja sellega, kuidas sa professionaalina töötad?“.

Seega ei ole professionaalne identiteet staatiline nähtus. See on meie isiksuse osa ja - nagu me isegi - pidevas arengus. Seetõttu tuleb professionaalse identiteedi eest kogu aeg hoolt kanda ja sellele tähelepanu pöörata. Oleme märganud, 
et kuigi professionaalse identiteedi eri tahkudega tuleks tegeleda kogu professionaalse arengu jooksul, pöörame sellele suhteliselt vähe tähelepanu või üldse mitte.

Professionaalne identiteet kujuneb üksikisikute ja nende keskkonna vastastikuse mõjutamise tulemusena. Professionaalne identiteet hõlmab seega meie suhteid iseenda ja teistega. See ühendab meid endid, teisi ja meie professiooni ning see on ainuomane vaid ühele professionaalile. Ruijtersi (2015a) sõnul annab tugev professionaalne identiteet professionaalile järgmised oskused:

- enesejuhtimine: võime valida oma rada, võttes arvesse oma organisatsiooni, elukutset ja isiklikke väljavaateid;

- vastupidavus: võime tulla toime muutuste ja arenguga, jäädes iseendaks;

- tarkus: meelerahu, mis võimaldab luua selgelt teistest eristuva identiteedi ja pakkuda lisandväärtust teiste identiteetidele;

- tipptase: sisemine tung ja tahe õppida, et anda endast parim ja oma professiooni tõeliselt nautida (Ruijters, 2015c).

Ruijtersi (2015a) professionaalse identiteedi mudel (vt joonist 3) koosneb kolmest peamisest osast: pool mudelist esindab sotsiaalset identiteeti, mida me tajume „meiena“, teine pool mudelist tähistab personaalset identiteeti, mina me tajume „minana“. Nende kahe poole kokkupuuteala esindab professionaalset identiteeti. Seega on mudelis esindatud neli elementi: alt ülespoole liikudes on need järgmised: personaalne mina, professionaalne mina, professionaalne raamistik ja institutsiooniline raamistik.

Personaalne mina koosneb materiaalsest minast (kõik, mille ette võime panna sõna "minu“ ja mille eest me tunneme end vastutavana), vaimsest minast (see, mis meid liikuma paneb) ja enese isiklikust esindatusest sotsiaalses minas (kuidas oleme seotud rühmade sees ja rühmadega) (James, 1890). Professionaalne mina koosneb enda loodud teooriast praktika kohta (isiklik arusaam sellest, kuidas asjad praktikas toimivad, enda kehtestatud professionaalsed normid ja väärtused), isiklikust teadmiste baasist (millised on sinu teoreetilised lemmikmudelid ja teadmised kontekstist, endast ja sellest, kuidas sa arened) ja sinu pädevusvaldkonnast (milles sa oled hea ja täiendad oma kolleege).

Seda kõike ümbritseb professionaalne raamistik, milles tuleb teha koostööd kolleegidega, kellega parajasti oma professionaalseid tegevusi kooskõlastad. See tähistab heade töötulemuste saavutamist rühmana (Shaffer, 2006).

Ning siis on veel institutsionaalne raamistik, mis tähendab organisatsiooni, milles töötad, religioosset kogukonda, milles sa osaled, või ühingut, mille liige sa oled. Sisuliselt pakub selline raamistik mitmeti tõlgendatavat skeemi, mis aitab inimestel „amorfsest, ebamäärasest, problemaatilisest olukorrast aru saada ja sellekohaselt tegutseda“" (Schön, 1983). Meie arvates näitab see, et igal institutsioonil või professionaalsel rühmal on oma mõtteviis, millest lähtudes 
sellesse kas kaasatakse või sellest välistatakse teatud mõtlemist ja tegevust eeldavad vaated või liikmed.

Nagu eespool mainitud, ei iseloomusta professionaalset identiteeti mitte pidevus ja muutumatus, vaid sidusus. Seega on professionaalsel identiteedil seos nii mineviku, oleviku kui ka tulevikuga. Seda tähistav ajatelg on tõmmatud joonisel 3 mudeli keskele. Mudeli keskel on sõrmejälg, mis sümboliseerib professionaalset identiteeti.

Professionaalne identiteet koosneb sellistest lahutamatutest osadest nagu kes sa oled (inimene), töö, mida sa teed (amet) ja keskkond, milles sa seda kujundad. See ei ole staatiline nähtus. See on meie enda osa ja - nagu meiegi areneb see pidevalt. Seega vajab professionaalne identiteet pidevat hoolt ja tähelepanu. Joonisel 3 on esitatud terviklik mudel, mis koosneb kolmest valdkonnast (personaalne, sotsiaalne ja professionaalne), mille põhjal tekib neli osa; personaalne mina, professionaalne mina, professionaalne raamistik ja institutsiooniline raamistik, mille keskel on professionaalne identiteet. Nool kujutab ajatelge, mis viitab pidevale arengule.

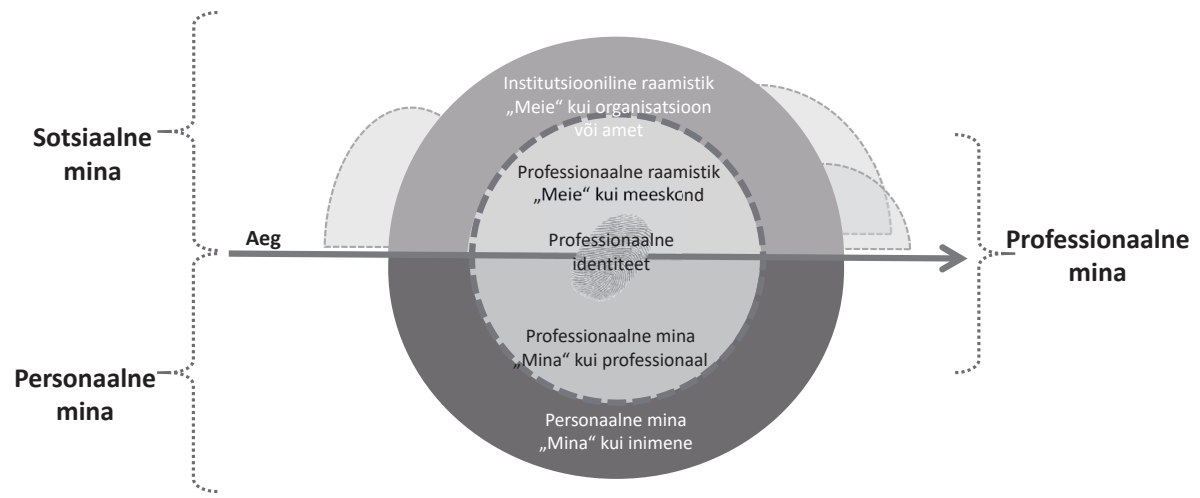

Joonis 3. Professionaalse identiteedi mudel.

\section{Kokkuvõttev arutelu}

Järgnevalt püüame kõik eelnevale viiele küsimusele vastates kokku võtta.

a) Millised on erinevused meie varasemate ja hilisemate professionalismi käsitlevate ja tööga seotud mudelite vahel?

b) Kuidas sobituvad õppimiseelistused meie õppemaastikuga?

c) Kuidas on professionaalne identiteet ja professionaalne õppimine omavahel seotud?

d) Milline võiks olla integreeritud ühendmudel?

e) Kuidas mõjutab see professionaalset õppimiskultuuri? 
a) Millised on erinevused meie varasemate ja hilisemate professionalismi käsitlevate ja tööga seotud mudelite vahel?

Oma esimestes artiklites (Simons \& Ruijters, 2001; 2004) kirjeldasime professionaali kui töötajat, kellel on kindel visioon, unikaalsed töömeetodid ning vajalikud teadmised ja oskused. Ühtlasi rõhutasime kutseorganisatsiooni kuulumise olulisust. Lisaks peaks professionaal õppimiseks kasutama kolme meetodit: selginemine, avardumine ja arendamine. Selle artikli koostamisel professionaalidele mõeldes hakkasime töökohal õppimist paremini mõistma. Leidsime, et liiga palju keskenduti õppimisele ja liiga vähe inimesele, kes õpib.

2014. aastal avaldatud artiklis (Simons \& Ruijters, 2014) uurisime professionaalide teemat edasi, toetudes kirjandusülevaatele. Tegime sammu professionaalide õppimisest professionaalse õppimiseni ning hakkasime professionalismi käsitlema kui valikut. Kirjeldasime professionaali kaheksat omadust. Esialgsed kolm ilmuvad kaheksa seas uuesti välja, kuid uute nimede all: visioonist sai pädevusvaldkond ning metoodikast, teadmistest ja oskustest sai tegevusteooria. Suhe professionaalse ühendusega muutus nüüd kutseliitude liikmelisuseks ja osalemiseks organisatsioonilises raamistikus. Kirjanduse ülevaatest lähtudes lisati uued professionalismi omadused: pühendumus, ausameelsus, pädevusvaldkond, autonoomsus ja autoriteet. Õppiva professionaali mudel sisaldas seega algseid kontseptsioone, mida oli oluliselt laiendatud.

Algselt eristatud professionaalide õppimise viisid (selginemine, avardumine ja arendamine) ilmusid taas õppemaastiku mudelis, kuid jagunesid siis juba saarteks, sildadeks ja poldriteks (vt allpool).

\section{b) Kuidas sobituvad óppimiseelistused meie óppemaastikuga?}

Õppemaastiku mudel (Ruijters, 2006; Ruijters \& Simons (2006) oli õppiva professionaali mudel, mis sobib selle sõna praeguse kasutusviisiga (professionaalid sõna laiemas tähenduses, mitte üksnes valitud rühmadesse kuuluvad või konkreetseid ameteid pidavad inimesed) ning tulenes meie mõttearendusest professionaalidelt õppimise teemal. Nüüdseks, kui kahte mudelit sageli üksteisega paralleelselt kasutatakse, kipub ikka ja jälle korduma küsimus: kuidas sobituvad õppimiseelistused õppemaastikuga.

Mõned meie üliõpilased püüdsid õppimiseelistusi õppemaastikku lõimida. Mõned neist pakkusid välja üsna atraktiivse ja lihtsa idee, et teadmiste omandamine võiks olla uurimissaarel, avastamine loomissaarel ning osalemine, harjutamine ja mõtestatud tajumine on kolm õppimisviisi, mida kasutatakse praktiseerimissaarel. Kui põhjalikumalt järele mõelda, siis selgub, et mõned õppimisviisid on pigem sillad ja poldrid. Harjutamine on sild uurimissaare ja praktiseerimissaare vahel, samuti sild loomissaarelt praktiseerimissaarele. Osalemine kuulub pigem poldritel toimuva kollektiivse integreeriva õppimise 
juurde. Mida rohkem me sellele mõtlesime, seda enam mõistsime, et kõik õppimisviisid võivad toimuda kõigil kolmel saarel. Mõelge näiteks tajumisele ja loomisele: loomekunsti omandamine oma ala eksperte jäljendades. Teine näide võib olla osalemine uurimissaarel: konverentsil käimine või kolleegidega teadusuuringutes osalemine. Lisaks leidsime ka muid seoseid sildade ja õppimisviiside vahel, näiteks uue viisi avastamine uute teadmiste rakendamiseks praktikasaarel või teadmiste omandamine selle kohta, kuidas uudsel viisil rakendada teadmisi uue tööriista loomiseks. Sama kehtib ka poldrite ja eespool kirjeldatud viie/seitsme õppimisviisi kohta. Kuigi siin on osalemine domineeriv õppimisviis, võivad ka ülejäänud neli kõne alla tulla.

Järelikult on viis/seitse õppimisviisi saartest, sildadest ja poldritest sõltumatud. Mõned seosed õppemaastiku osade ja õppimiseelistuste vahel on teistest tugevamad, kuid mingeid välistavaid seoseid ei näi leiduvat.

\section{c) Kuidas on professionaalne identiteet ja professionaalne óppimine omavahel seotud?}

Professionaalne identiteet annab professionaalile vundamendi, millele toetudes määrata pikaajalised perspektiivid (minevik, olevik ja tulevik), suhestuda oma isikliku identiteediga ning asetada end ümbritsevasse keskkonda ja organisatsiooni. See tagab isikliku ja professionaalse arengu tervikliku lõimumise organisatsiooni ja professiooni kontekstis. Kuidas tekkis teie materiaalse, sotsiaalse ja vaimse mina baasil teie isiklik ja professionaalne identiteet? Kuidas tekkis raamistik, millega te end tänu oma organisatsioonile ja professioonile seostate? Tugev professionaalne identiteet tähendab teadlikku valikut olla professionaal ning täita eespool kirjeldatud kaheksat professionaalile seatud kriteeriumi ning kaheksat professionaalse õppimise mudelis kirjeldatud kriteeriumi. Professionaalsel identiteedil on ka sisuline mõõde: millise ametiga te tunnete end seotud olevat (advokaat, arst, õpetaja, õde jne) ja kui tugevalt?

Kui varem keskendusime peamiselt kaudsele ja otsesele õppimisele, siis professionaalsest identiteedist mõtisklemine näitas meile, kuivõrd oluline on individuaalse ja kollektiivse õppimise ühendamine (Ruijters, 2015a).

\section{d) Milline võiks olla integreeritud ühendmudel?}

Lähtudes oma huvist õppimise ja professionaalide vastu, oleme aastate jooksul laiendanud ja süvendanud oma teadmisi ja arusaamu selles valdkonnas. Jäme üha kindlamalt seisukohale, et professionaal peab pidevalt õppima, et pakkuda praegusele ühiskonnale jätkuvalt lisandväärtust. Viimastesse uurimustesse lisasime ka identiteedi, sest märkasime, et identiteet mängib meie tööalalases eksistentsis üha olulisemat rolli. 
Nüüdseks oleme jõudnud punkti, kus otsime seost professionalismi, õppimise ja identiteedi vahel. Seda seetõttu, et üha enam kinnistub veendumus, et kõige olulisem ei ole see, kuidas õpitakse, vaid õppimise muutumine identiteedi osaks. Seega otsime óppija identiteeti ehk seda, mis kuulub lahutamatu osana ühe või teise inimese óppimisviisi juurde ja näitab, milline óppija ta on ja olla tahab. Seejuures võtame arvesse oma varasemate mudelite ja artiklitega seoses saadud õppetunde ja vaatame, mida õpetavad need meile professionaali kui õppija identiteedi kohta ning milliseid küsimusi peab ta selle kujundamiseks esitama.

Identiteeti puudutavad küsimused on järgmised.

a) Ajatelg: kuidas on toimunud õppimine teie elu eri etappides? Kuidas on toimunud õppimine teie professionaalse elu eri etappides? Kuidas õpite praegu ja milliseks soovite selle tulevikus kujundada?

b) Meie - keskkond - kollektiivne mina: milliste keskkondadega (instituudid, organisatsioonid, meeskonnad) olete seotud?

c) Personaalne/professionaalne mina: kuidas te ennast tunnete? Milline on teie materiaalne mina? Milline on teie vaimne mina? Milline on teie sotsiaalne mina? Mis iseloomustab teie teadmisi? Mis iseloomustab teie pädevusvaldkonda? Mis iseloomustab teie teoreetilisi teadmisi praktika kohta?

d) Professionaalne identiteet: mis iseloomustab seoseid teie ameti, teie ja teie organisatsiooni vahel?

Professionalismi puudutavad küsimused on järgmised.

e) Professionaal: millisele valdkonnale olete pühendunud? Mida tähendab teie jaoks ausameelsus? Millised on põhiteadmised teie kutsealal? Millised on teie professioonile omased teooriad praktika kohta? Mis on teie pädevusvaldkond teie ametialal? Milline on see professionaalne raamistik, milles töötate? Milline autonoomia on omane teie ametile? Milline autoriteet on teie ametil?

f) Õppiv professionaal: kuidas säilitada oma professionaalsust? Kuidas te mõtestate dilemmasid? Kuidas ühendate teadusuuringud ja praktika? Kuidas tagate reflektiivse praktika? Kuidas täiendate oma teadmisi? Millistesse professionaalsetesse kogukondadesse kuulute? Kuidas arendate end professionaalina? Kuidas panustate oma kolleegide arengusse?

Õppimist puudutavad küsimused on järgmised.

g) Õppemaastik: milline on teie isiklik õppemaastik?

h) Oppimiseelistused: mis iseloomustab teie õppimisviisi? 
Need küsimused ei ole muidugi rangelt eraldatud. Teiste valdkondadega seostamisel saavad kõik küsimused sügavama tähenduse. Näiteks saab oma õppimist meeskonnas süvendada piki ajatelge, kuid ka õppimiseelistuste kaudu.

Lõpuks on siiski kõige olulisem küsimus: mis on sinu õppimises unikaalset, võttes arvesse sinu keskkonda ja ametit? Meie arvates tagaks selle küsimuse kallal töötamine nii baaskoolituse kui ka hilisema professionaalse tegutsemise ajal suurema kindlustunde professionaalina. Oleme koondanud ja omavahel ühendanud kõik eespool loetletud küsimused tabelisse 1 .

\section{e. Kuidas mõjutab see professionaalset óppimiskultuuri?}

Mida saavad organisatsioonid ja nende juhid ära teha, et aidata kaasa sellise õppimiskultuuri tekkele, mis aitab professionaalidel säilitada professionalismi, professionaalset identiteeti ning arendada end opppivate professionaalidena? Vastus sellele küsimusele on lihtne: pakkuda professionaalset keskkonda, kus professionaalid saavad end edasi täiendada õppiva professionaali mudeli kaheksa omaduse kohaselt.

See tähendab järgmist.

- Elukestva õppe hõlbustamine.

- Reflektiivsete arutelude korraldamine praktikas ja kutsealal laiemalt ette tulevate professionaalsete dilemmade, normide ja väärtuste arutamiseks.

- Ligipääsu võimaldamine teadusuuringutele ja teooriatele.

- Mõttepauside tegemine professionaalse tegevuse üle reflekteerimiseks.

- Võimaluse andmine isikliku pädevuse suurendamiseks.

- Professionaalsetes ning õppimise ja organisatsioonilise õppimisega seotud ühendustes osalemise toetamine.

- Iseseisvuse võimaldamine tööl ja õppimisprotsessis.

- Kutseala toetamine ning algajate ja professionaalidest kolleegide õpetamine. 


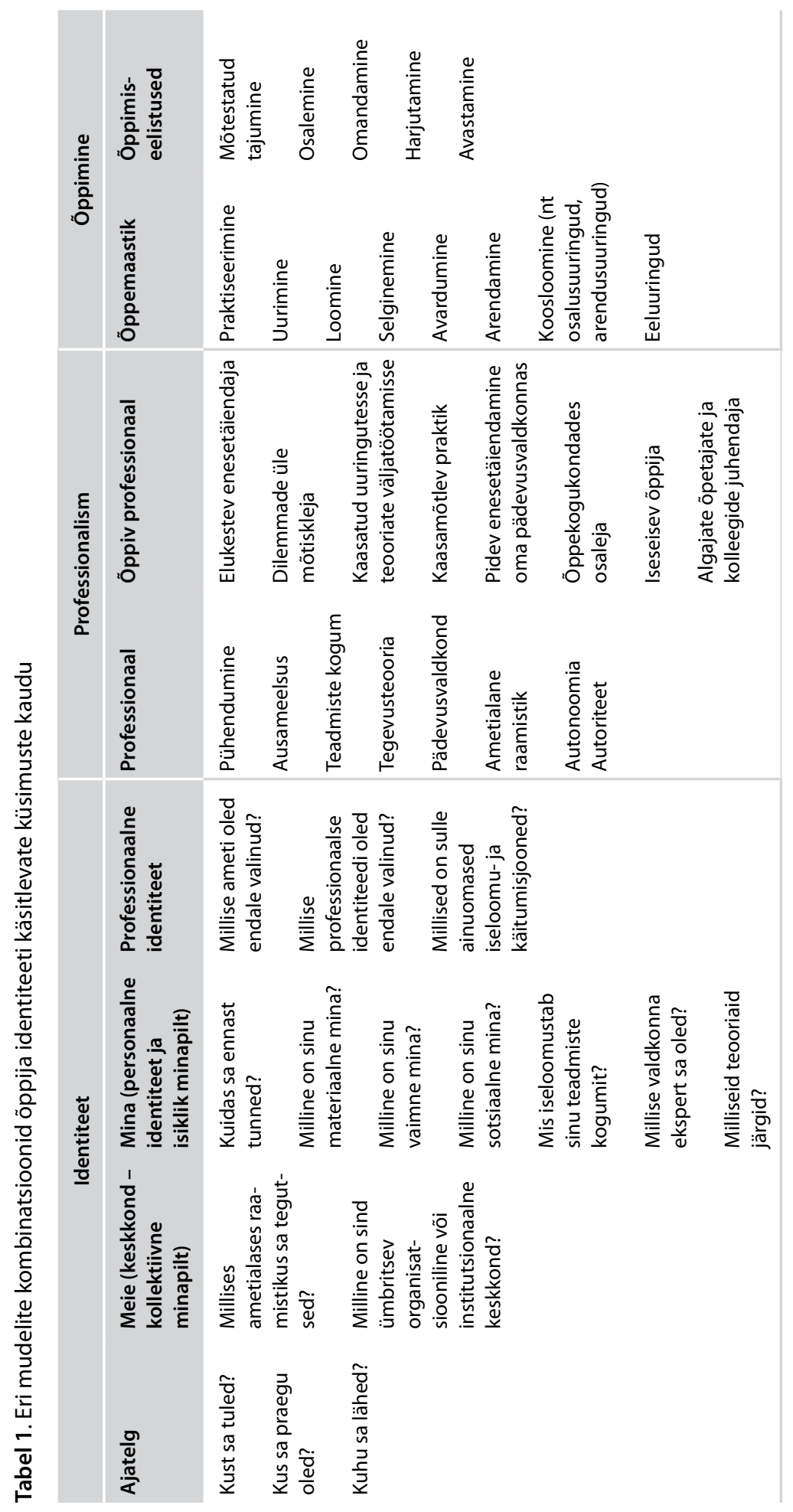




\section{Kokkuvõte}

See artikkel võtab kokku meie varasemad artiklid ja uurimused professionalismi, professionaalse õppimise, organisatsioonilise õppimise ja professionaalse identiteedi kohta. Peamine eesmärk oli siiski nende valdkondade lõimimine. Seda võiks teha õppija identiteedi mõiste kasutuselevõtu kaudu ehk selle kaudu, mis kuulub lahutamatu osana ühe või teise inimese óppimisviisi juurde ja näitab, milline õppija ta professionaalina on ja olla tahab. Selle kontseptsiooni aluseks on professionaalne identiteet (oma ajalise arengutelje ning personaalse ja sotsiaalse mina vaheliste seostega) ning valik olla professionaal ja jääda selleks. Siin on ühendatud omal valikul professionaali organisatsioonilised ja professionaalsed kollektiivsed raamistikud ning sellega määratletakse nii õppiva professionaali õppimise valdkonnad kui ka õppimiseelistused. Lisatud küsimuste tabel aitab professionaalil oma õppija identiteeti üksikasjalikumalt kaardistada. Õppiva professionaali omadusi saab tõlgendada kui professionaalse õppimiskultuuri kaheksat tunnust: see on keskkond, mida organisatsioonid peavad professionaalidele pakkuma, kui tahetakse, et nad saaksid ja jääksid õppivateks professionaalideks.

Siinne uurimus keskendub õppija identiteedi mõiste edasiarendamisele ja professionaalse õppimiskultuuri tekke toetamisele. Meie edaspidine töö keskendub ka organisatsioonilise ja professionaalse õppimise vahelistele suhetele.

\section{Kasutatud kirjandus}

Bandura, A. (1986). Social foundations of thought and action: A social cognitive theory. Englewood Cliffs: Prentice-Hall.

Bereiter, C. (2002). Education and mind in the knowledge age. Hillsdale: Erlbaum.

Berings, M.G.M.C. (2006). On-the-job learning styles: conceptualization and instrument development for the nursing profession. PhD. Tilburg: Tilburg University.

Bolhuis, S. M. (1995). Leren en veranderen bij volwassenen. Een nieuwe benadering. [Learning and change with adults: a new approach]. Bussum: Coutinho.

Bruner, J. (1996). The culture of education. Cambridge: Harvard University Press.

Doornbos, A. J. (2006). Work related learning at the Dutch police force. PhD. Nijmegen: Radboud University.

Engeström, Y. (1999). Innovative learning in work teams: Analyzing cycles of knowledge creation in practice. In Y. Engeström, R. Miettinen, R.-L. Punamäki (Eds.), Perspectives on activity theory (pp. 377-404). Cambridge: Cambridge University Press. https://doi.org/10.1017/CBO9780511812774.025

Ericsson, K. A., Krampe, R. T., \& Tesch-Romer, C. (1993). The role of deliberate practice in the acquisition of expert performance. Psychological Review, 100(3), 363406. https://doi.org/10.1037/0033-295X.100.3.363 
Freidson, E. (2001). Professionalism: the third logic. Chicago: The University of Chicago Press.

Gardner, H., \& Shulman, L. S. (2005). The professions in America today: Crucial but fragile. Daedalus, 134, 13-18. https://doi.org/10.1162/0011526054622132

Greenwood, E. (1957). Attributes of a profession. Social work, July, 45-55.

Illeris, K. (2014). Transformative learning and identity. New York: Routledge.

James, W. (1890). The Principles of Psychology. Adelaide (Australia): eBooks@Adelaide. The University of Adelaide Library. University of Adelaide.

Kegan, R. (2009). What 'form' transforms? A constructive-developmental approach to transformative learning. K. Illeris (Ed.), Contemporary theories of learning (pp. 35-52). New York: Routledge.

Meggison, D. (1996). Planned and emergent learning. Management Learning, 27, 411-428. https://doi.org/10.1177/1350507696274002

Nolin, J. (2008). In search of a new theory of professions. Report of the University of Borås (Sweden) in the series Science for the professions, 4, 1-53.

Nonaka, I., \& Takeuchi, H. (1995). The knowledge-creating company: How Japanese companies create the dynamics of innovation. New York: Oxford University Press.

Paavola, S., Lipponen, L., \& Hakkarainen, K. (2002). Epistemological foundations for CSCL: A comparison of three models of innovative knowledge. G. Stahl (Ed.), Proceedings of CSCL 2002 (pp. 24-32). Hillsdale: Erlbaum. https://doi.org/10.3115/1658616.1658621

Ruijters, M. C. P. (2006). Liefde voor leren [Love for learning]. Doctoral dissertation, Utrecht University.

Ruijters, M. C. P., \& Simons, P. R. J. (2006). Het leerlandschap van organisaties [The learning landscape of organizations]. Develop, 2, 54-63.

Ruijters, M. C. P. (Ed.) (2015a). Je binnenste buiten. Over professionele identiteit in organisaties. [Your inside out. About professional identity in organizations]. Deventer: Vakmedianet.

Ruijters, M. C. P. (2015b). Praktijkverkenningen. [Exploring practice] M. C. P. Ruijters (Ed.), Je binnenste buiten. Over professionele identiteit in organisaties. [Your inside out. About professional identity in organizations] (pp. 145-190). Deventer: Vakmedianet.

Ruijters, M. C. P. (2015c). Professionele identiteit. [Professional identity]. In M. C. P. Ruijters (Ed.), Je binnenste buiten. Over professionele identiteit in organisaties. [Your inside out. About professional identity in organizations] (pp. 191-240). Deventer: Vakmedianet.

Ruijters, M. P. C., \& Simons, P. R. J. (2015). Professionaliteit [Professionality]. M. C. P. Ruijters (Ed.), Je binnenste buiten. Over professionele identiteit in organisaties. [Your inside out. About professional identity in organizations] (pp. 59-98). Deventer: Vakmedianet.

Schön, D. (1983). The reflective practitioner: How professionals think in action. New York, NY: Basic Books.

Senge, P. (1990). The fifth discipline: the art and practice of the learning organization. London: Random House.

Sfard, A. (1998). On two metaphors for learning and the dangers of choosing just one. Educational Researcher, 27, 4-13. https://doi.org/10.3102/0013189X027002004 
Shaffer, D. W. (2006). How Computer Games Help Children Learn. New York: Palgrave Macmillan.

Simons, P. R. J., \& Ruijters, M. C. P. (2001). Work related learning: Elaborate, expand, externalise. In L. Nieuwenhuis (Ed.), Dynamics and stability in VET and HRD (pp. 101-114). Enschede: Twente University Press.

Simons P. R. J., \& Ruijters M. C. P. (2004). Learning Professionals: Towards an Integrated Model. H.P.A. Boshuizen, R. Bromme, \& H. Gruber (Eds.) Professional Learning: Gaps and Transitions on the Way from Novice to Expert. Innovation and Change in Professional Education (pp. 207-229). Dordrecht: Springer. https://doi.org/10.1007/1-4020-2094-5_11

Simons, P. R. J., \& Ruijters, M. C. P. (2008). Varieties of work-related learning. International Journal of Educational Research, 47(4), 241-251. https://doi.org/10.1016/j.ijer.2008.07.001

Simons, P. R. J., \& Ruijters, M. C. P. (2014). The real professional is a learning professional. S. Billet, C. Harteis \& H. Gruber (Eds.), International Handbook of research in professional and practice based learning (pp. 955-985). Berlin: Springer. https://doi.org/10.1007/978-94-017-8902-8_35

Thijssen, J. (1987). Bedrijfsopleidingen als werkterrein. [Training and development as field of work]. Den Haag: Vuga.

Van Oeffelt, T., Ruijters, M. C. P., Van Hees, A., \& Simons, P. R. J. (2017). Professional identity, a neglected core concept of professional development. K. Black, R. Warhurst, \& S. Corlett (Eds.), Identity as a Foundation for Human Resource Development (pp. 237-252). London: Taylor \& Francis. https://doi.org/10.4324/9781315671482-16

Van Oeffelt, T. P. A., Ruijters, M. C. P., \& Wempe, J. F. D. B. (2020). Towards collective professionalism: Lessons from a systematic review of literature on the history of professionalism. Manuscript in preparation. 